\title{
ON THE PHORESY AND MORPHOLOGY OF PAVANIA CARABIDOPHILA KHAUSTOV, 2005 (ACARI: DOLICHOCYBIDAE)
}

\author{
Alexander A. Khaustov ${ }^{*}$ and Viacheslav A. Trach $^{2}$
}

${ }^{1}$ Tyumen State University, Tyumen, Russia

${ }^{2}$ I. I. Mechnikov Odessa National University, Odessa, Ukraine

*corresponding author; e-mail: alkhaustov@mail.ru

ABSTRACT: The phoresy of Pavania carabidophila Khaustov, 2005 (Acari: Dolichocybidae) on the carabid beetle Bembidion (Plataphus) lucillum Bates, 1883 (Coleoptera: Carabidae) is documented for the first time with the aid of SEM microscopy. Supplementary description of previously unknown characters of $P$. carabidophila is provided. The attachment sites and type of attachments of dolichocybid mites are discussed.

KEY WORDS: Mites, carabid beetles, SEM microscopy, attachment.

DOI: 10.21684/0132-8077-2017-25-1-25-28

\section{INTRODUCTION}

The Dolichocybidae family is a small group of the early derivative heterostigmatic mites, which currently includes 2 subfamilies, 6 genera and 39 species in the world fauna (Hajiqanbar and Khaustov 2010; Rahiminejad et al. 2011; Zhang et al. 2011; Loghmani et al. 2013; Bahramian et al. 2015). Little is known about the way of life of the dolichocybid mites, but, probably, all of them are fungivorous (Rack 1967; Magowski 1988; Kaliszewski et al. 1995). Adult females of dolichocybid mites utilize various insects for phoresy. Most dolichocybids are phoretic on various beetles of the families Bostrichidae, Carabidae, Curculionidae, Prostomidae, Scarabaeidae, Silvaniidae and Tenebrionidae (Sevastianov 1980; Magowski and Moser 1993; Khaustov 2005; Hajiqanbar and Khaustov 2010; Rahiminejad et al. 2011; Loghmani et al. 2013; Katlav et al. 2014, 2015; Bahramian et al. 2015; Mortazavi et al. 2015); mites of the genus Formicomotes Sevastianov, 1980 are phoretic on ants (Sevastianov 1980). Mites from the genera Acanthomastix, Dolichocybe, Dolichomotes and the carabid-associated Pavania are phoretic under the elytra of beetles (Rahiminejad et al. 2011; Katlav et al. 2014; Mortazavi et al. 2015); scarabaeid-associated species usually attach to a soft membrane between head and pronotum, or between pronotum and elytra (Loghmani et al. 2013; Katlav et al. 2015). The mechanism of attachment of dolichocybid female to host beetle is unknown.

Pavania carabidophila Khaustov, 2005 was described from under elytra of the carabid beetle Bembidion sp. from southern part of the European Russia (Khaustov 2005). We collected one specimen of the beetle Bembidion (Plataphus) lucillum Bates, 1883 (Coleoptera: Carabidae) from the Far
East of Russia containing numerous females of Pavania carabidophila under its elytra. We studied the attachment of $P$. carabidophila females with the aid of SEM microscope for the first time. During the study of $P$. carabidophila using the compound microscope, some new morphological characters were revealed and their supplementary description is provided in this article.

\section{MATERIAL AND METHODS}

A living beetle Bembidion (Plataphus) lucillum Bates, 1883 was collected by junior author in Primorsky Krai, Lazo, 43 30' 04.6" N, 133 34' 47.1" E, $902 \mathrm{~m}$ a.s.1., 28 August 2016, on the bank of the stream. The beetle was brought to the laboratory at Tyumen State University and inspected for phoretic mites with the aid of the stereomicroscope Discovery V8 (Carl Zeiss, Germany). Alive mites attached to beetle without right elytron were scanned without dusting with the aid of a JEOLJSM-6510LV SEM microscope. After that, mites were removed from the beetle and mounted on slides in Hoyer's medium. The identification of mites was provided with the aid of an AxioImager A2 compound microscope (Carl Zeiss, Germany) with phase contrast and DIC objectives. Micrographs were taken with the aid of digital camera Hitachi KP-HD20A. Terminology follows mostly that of Lindquist (1986). All mites are deposited in the mite collection of the Tyumen State University Museum of Zoology, Tyumen, Russia.

\section{RESULTS}

All phoretic mites were located in two large groups on tergites covered by left and right elytra 

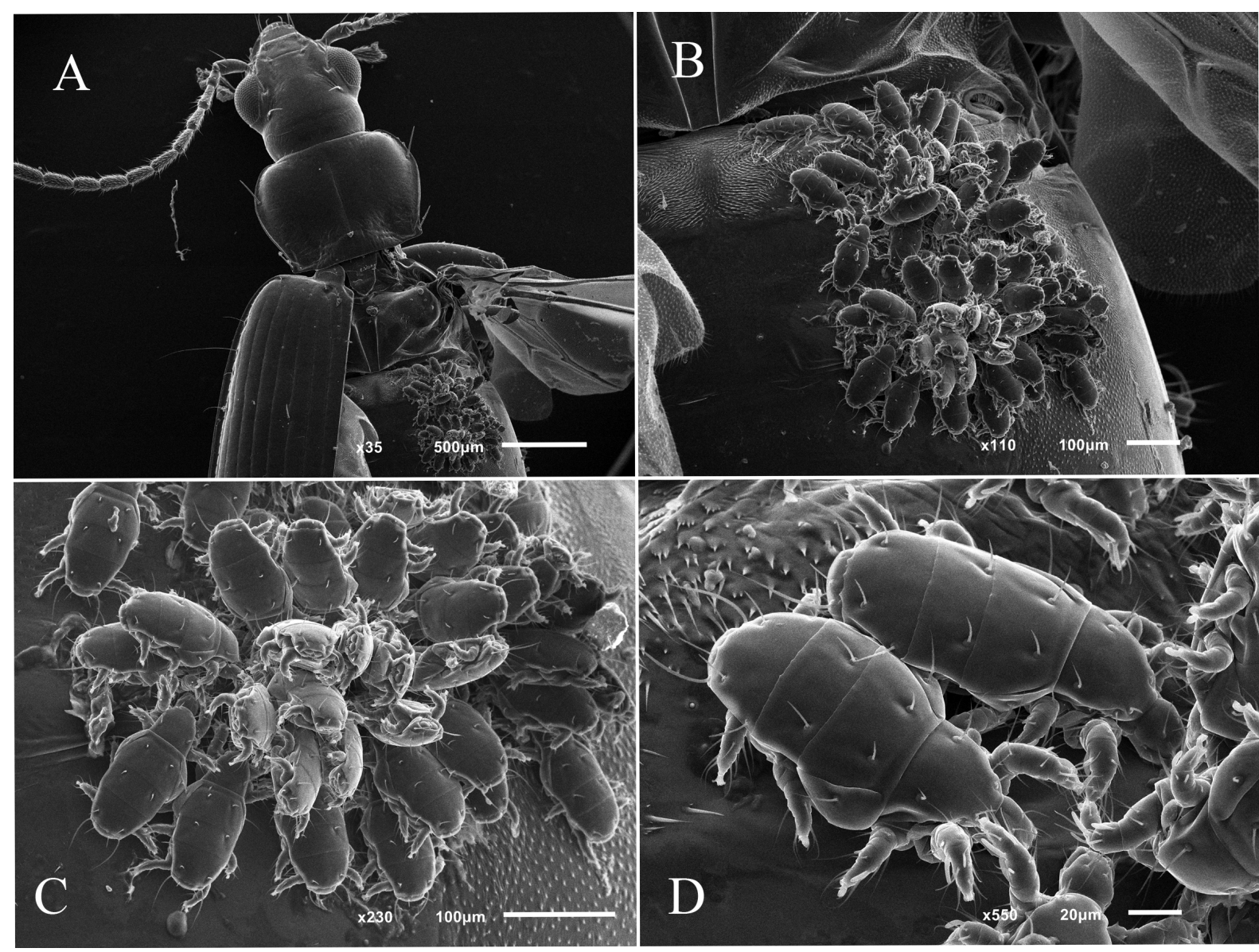

Fig. 1. SEM photos of females of Pavania carabidophila Khaustov, 2005 under elytra of Bembidion lucillum Bates, 1883 (right elytron removed): A—general view; B-D—detailed view.

(Fig. 1). Each group of mites consists of approximately 60 individuals. Most of the mite specimens were attached to the soft membrane of lateral parts of anterior abdominal tergites (Figs. 1A, B). Mites in each large group were oriented to particular small area; individuals above this area oriented vertically and tightly to each other (Fig. 1C). All individuals of mites were attached by their mouthparts to beetle host (Fig. 1D). The mechanism of attachment of mite gnathosoma to beetle membrane is not clear. Potentially, it could involve insertion of cheliceral stylets and pinching with palptibial claws.

\section{Supplementary description of previously unknown characters of $P$. carabidophila}

During this study, we found some morphological characters which were not illustrated in the original description of Pavania carabidophila. The most remarkable character is the presence of spinelike processes on trochanters I and II (Fig. 2A). Trochanter I with 5-6 dorsal processes; trochanter II with two processes. Such spine-like processes previously have never been recorded in any species of Pavania. Another unusual character found in P. carabidophila is the presence of cone-like subcuticular structure located laterally to setae $1 b$ (Fig. 2C). This structure has never been found in any dolichocybid mite. Tarsus I of $P$. carabidophila with ventrodistal membranous flange (Fig. 2D). This structure has never been found in any dolichocybid mite. Our examination of other available species of Pavania revealed the presence of this flange in all species. We also discern pharynx of $P$. carabidophila. It is narrow, with weak lateral projections (Fig. 2B). The pharynx of P. carabidophila considerably differs from scarabaeid-associated species of Pavania (see Fig. 3 in Bahramian et al. 2015), which have more short and wide pharynx with relatively long lateral projections.

\section{DISCUSSION}

A similar type of location of phoretic dolichocybid mite on a beetle host was recently documented for Acantomastix derivatus Katlav and Hajiqanbar, 2014 (Katlav et al. 2014). Females of this species are also attached to soft cuticle between 


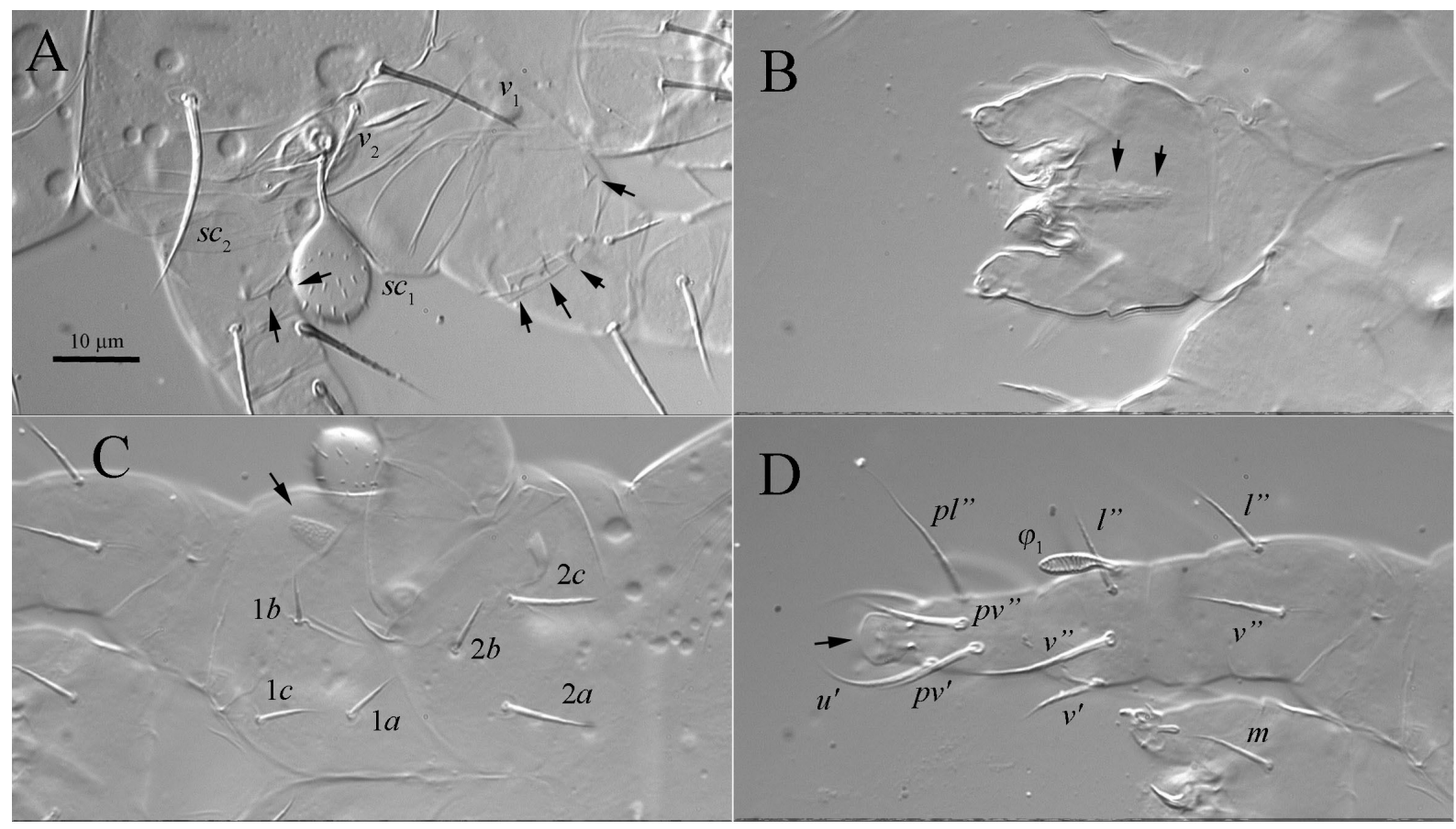

Fig. 2. DIC micrographs of females of Pavania carabidophila Khaustov, 2005: A-lateral part of prodorsum and bases of legs I and II; arrows point to spine-like processes; B - pharynx; C-lateral part of ventral propodosoma; arrow points to cone-like structure; D-leg I in ventral view; arrow points to membranous flange.

tergites on anterolateral corners of dorsal abdomen of host beetles Uloma culinaris (Linnaeus, 1758) and Prostomis sp. Dolichocybid mites located on anterolateral corners of dorsal abdomen beneath the elytra of beetles probably because it is the most protected place from the wind during the beetle's flight. Such attachment to the host by gnathosoma during phoresy is unique among Heterostigmata. Only mites of the family Caraboacaridae exhibit a similar behavior. Nickel and Elzinga (1969) observed insertion of chelicerae of Caraboacarus karenae Nickel and Elzinga, 1969 into hind wings of carabid beetles. However, caraboacarid mites attached to the host mainly by modified sucker-like setae $1 a$ and very large empodia on legs II-IV. The characteristic insertion of gnathosoma of dolichocybid mites into soft cuticle of host beetles suggests that they can acquire at least a liquid from the beetles. Kaliszewski et al. (1995) considered phoresy as preadaptation to permanent parasitism. In our opinion, phoresy in dolichocybid mites looks like the first step towards parasitism. The parasitic way of life is evident for the Crotalomorphidae, the second family of the superfamily Dolichocyboidea, the parasites of carabid beetles (Lindquist and Krantz 2002). On other hand, dolichocybid mites could suck a liquid from their hosts during phoresy. Such phenomenon was evident for heteromor- phic deutonymphs of astigmatid mite Hemisarcoptes cooremani (Astigmata: Hemisarcoptidae), which at least acquired water from the hemolymph of host beetle Chilocorus cacti (Coleoptera: Coccinellidae) via caudal ventral suckers (Houck and Cohen 1995).

We do not know whether the dolichocybid mites acquire the material from beetle hosts or not. Further studies are required to solve this question.

\section{ACKNOWLEDGEMENTS}

The authors thank Dr. Kirill Makarov (Moscow State Pedagogical University, Moscow, Russia) for the identification of carabid beetle, and Andrey Bobylev (Tyumen State University, Tyumen, Russia) for his help with SEM micrographs.

\section{REFERENCES}

Bahramian, M., Hajiqanbar, H. and Talebi, A.A. 2015. Two heterostigmatic mite species (Acari: Dolichocybidae, Podapolipidae) associated with Scarabaeus pius (Coleoptera: Scarabaeidae) from Iran. Acta Zoologica Academiae Scientiarum Hungaricae, 61: 25-32.

Hajiqanbar, H. and Khaustov, A.A. 2010. A new species group and five new species of the genus Pavania (Acari: Dolichocybidae) associated with insects, with notes on leg chaetotaxy and the distribution 


\section{A. A. Khaustov and V. A. Trach}

of genera. European Journal of Entomology, 107: $441-453$.

Houck, M.A. and Cohen, A.C. 1995. The potential role of phoresy in the evolution of parasitism: radiolabelling (tritium) evidence from an astigmatid mite. Experimental \& Applied Acarology, 19: 677-694.

Kaliszewski, M., Athias-Binche, F. and Lindquist, E.E. 1995. Parasitism and parasitoidism in Tarsonemina (Acari: Heterostigmata) and evolutionary considerations. Advances in Parasitology, 35: 335-367.

Katlav, A., Hajiqanbar, H. and Talebi, A.A. 2014. First record of the genus Acanthomastix Mahunka, 1972 (Acari: Dolichocybidae) from Asia, with the description of a new species. International Journal of Acarology, 40: 7-14.

Katlav, A., Hajiqanbar, H. and Talebi, A.A. 2015. A contribution to the knowledge of heterostigmatic mites (Acari: Prostigmata) in western Mazandaran Province, Northern Iran. Acarologia, 55: 311-320.

Khaustov, A.A. 2005. Two new mite species of the genus Pavania (Heterostigmata, Dolichocybidae) from the Crimea and Southern European Russia. Zoologicheskiy Zhurnal, 84: 1516-1521. [in Russian]

Lindquist, E.E. 1986. The world genera of Tarsonemidae (Acari: Heterostigmata): a morphological, phylogenetic, and systematic revision, with a reclassification of family-group taxa in the Heterostigmata. Memoirs of Entomological Society of Canada, 118: 1-517.

Lindquist, E.E. and Krantz, G.W. 2002. Description of, and validation of names for, the genus Crotalomorpha and the family Crotalomorphidae (Acari: Heterostigmata). Systematic \& Applied Acarology, 7: 129-142.

Loghmani, A., Hajiqanbar, H., Talebi, A.A. 2013. A new species group and species of the genus Pavania (Acari: Dolichocybidae), phoretic on $\mathrm{On}$ thophagus vitulus (Coleoptera: Scarabaeidae) from Iran. Zootaxa, 3693(3): 320-328.

Magowski, W.L. 1988. Description of a new species of Formicomotes Sevastianov, 1980 (Acari: Doli- chocybidae) with notes on the female dimorphism within this genus. Mitteilungen aus dem Hamburgischen Zoologischen Museum und Institut, 85:163-182.

Magowski, W.L. and Moser, J.C. 1993. Three new species of the genus Acanthomastix Mahunka, 1972 from United States and Poland (Acari: Dolichocybidae). Entomologische Mitteilungen aus dem Zoologischen Museum Hamburg, 11(147): 1-20.

Mortazavi, A., Hajiqanbar, H. and Kamali, K. 2015. A new species of the family Dolichocybidae Mahunka, 1970 (Acari: Heterostigmata) associated with Sinoxylon pugnax Lesne (Coleoptera: Bostrichidae) from Iran. Systematic \& Applied Acarology, 20: 441-448.

Nickel, P.A. and Elzinga, R.J. 1969. Caraboacarus karenae, a new mite from carabid beetles, with notes on its biology. Journal of the Kansas Entomological Society, 42: 222-229.

Rack, G. 1967. Untersuchungen uber die biologie von Dolichocybe Krantz, 1957 und beschreibung von zwei neuen Arten (Acarina, Pyemotidae). Mitteilungen aus dem Hamburgischen Zoologischen Museum und Institut, 64: 29-42.

Rahiminejad, V., Hajiqanbar, H. and Fathipour, Y. 2011. Redefinition of the genus Dolichocybe (Acari: Dolichocybidae), with description of two new species associated with insects. Annales of the Entomological Society of America, 104: 627-635.

Sevastianov, V.D. 1980. New taxa of mites of the family Dolichocybidae (Trombidiformes, Tarsonemina) and phylogenetic relations of its subfamilies. Zoologicheskiy Zhurnal, 59: 1453-1462 [in Russian].

Zhang, Z.-Q., Fan, Q.-H., Pesic, V., Smit, H., Bochkov, A.V., Khaustov, A.A., Baker, A., Wohltmann, A., Wen, T.-H., Amrine, J.W., Beron, P., Lin, J.-Z., Gabrys, G. and Husband, R. 2011. Order Trombidiformes Reuter, 1909. In: Zhang, Z-Q. (ed.) Animal biodiversity: an outline of higher-level classification and survey of taxonomic richness. Zootaxa, 3148: 129-138. 